International Journal of Current Microbiology and Applied Sciences

ISSN: 2319-7706 Volume 6 Number 6 (2017) pp. 2648-2655

Journal homepage: http://www.ijcmas.com

Original Research Article

https://doi.org/10.20546/ijcmas.2017.606.315

\title{
Evaluation of Plant Growth Promoting Rhizobacteria and Mycorrhizal Fungi for Growth and Nutrient Uptake in Pearl Millet (Pennisetum glaucum)
}

\author{
Prashant Singh ${ }^{1,6^{*}}$, Hem C. Joshi², Naveen Kumar ${ }^{3}$, Manish Dev Sharma ${ }^{4}$, \\ Aditya Patel ${ }^{6}$, Narotam Sharma ${ }^{6}$ and Veena Pandey ${ }^{1}$ \\ ${ }^{1}$ Department of Biotechnology, Bhimtal Campus, Kumaun University, Nainital, \\ Uttarakhand, India \\ ${ }^{2}$ Department of Plant Physiology, ${ }^{3}$ Molecular Cytogenetics Laboratory, Department of Molecular \\ Biology and Genetic Engineering, Govind Ballabh Pant University of Agriculture and \\ Technology Pantnagar, India \\ ${ }^{4}$ Department of Life Sciences, ${ }^{5}$ Central Molecular Research Laboratory, Biochemistry \\ Department, Shri Guru Ram \\ Rai Institute of Medical and Health Sciences, Dehradun, India \\ ${ }^{6}$ Devsthali Vidhyapeeth, Lalpur, U S Nagar, India \\ *Corresponding author
}

\section{A B S T R A C T}

Keywords

PGPR, Mycorrhiza,

Nutrient uptake,

Agronomical traits.

Article Info

Accepted:

26 May 2017

Available Online:

10 June 2017
Five bacterial cultures and one mycorrhiza culture were applied on seeds of Pearl millet (Pennisetum glaucum L.). All the bacterial cultures and mycorrhiza showed increased agronomical traits and enhancement in nutrient uptake like potassium, nitrogen and phosphorus. Seedlings treated with bacteria and mycorrhiza also analyzed for flavonoids, phenols and super oxide dismutase (SOD). Increased level of phenols, flavonoids and SOD confirmed microorganism effect on plant growth promotion. PS-05 and mycorrhiza were most effective in plant growth promoting activities.

\section{Introduction}

Current trends in agriculture are focused on reduction in the use of chemical pesticides and inorganic fertilizers, compelling the search for alternatives that enhance environmental quality (Haggag, 2002). The management of soil organic matter requires inputs of biological fertilizers, composts, crop residues, green manure, and other organic wastes. The role of microbes in maintaining soil fertility is well known and recently plant growth promoting microbes were identified by researchers worldwide. Plant growthpromoting bacteria (PGPB) directly stimulate growth by nitrogen fixation (Han et al., 2005), solubilisation of nutrients (Rodriguez and Fraga, 1999), production of growth hormones, 1amino-cyclopropane-1carboxylate (ACC) deaminase (Correa et al., 2004); and indirectly by antagonizing pathogenic fungi by production of siderophores, chitinase, $\beta$-1,3-glucanase, antibiotics, fluorescent pigments, and cyanide 
(Renwick et al., 1991; Pal et al., 2001). Majority of known plant growth-promoting rhizobacteria (PGPR) are isolated from rhizosphere (Khalid et al., 2004). However, their ability to colonize roots and survive in soil is often limited (Normander and Prosser 2000). Identification of more potent bacteria and fungi can broaden the spectrum of PGPB and mycorrhiza that can survive and perform well in soil conditions.

Pearl millet [Pennisetum glaucum (L.)] is the main coarse grain crop in semi-arid regions and is grown in India as rain-fed or irrigated crop on 10 million hectares producing 7.01 million tons (Bhatnagar et al., 2002). Pearl millet is a crop of marginal land, provides staple food for poor in semiarid regions of Asia and Africa. Improving the soil fertility and millet production without the use of chemical fertilizers is a difficult task (Raj et al., 2003). But chemical fertilizers have detrimental effect on soil hence PGPR and mycorrhiza use may be best approach for millet production. PGPR-mediated plant growth and control of plant diseases of pearl millet is an alternative eco-friendly approach (Kloepper, 1993).

In the present study, effect of previously isolated and identified bacteria and mycorrhiza were evaluated for nutrient uptake like phosphorus, nitrogen, potassium and other morphological and biochemical effect on cultivation of Pearl millet.

\section{Materials and Methods}

\section{Bacterial culture}

Five bacterial cultures were isolated, characterized and named as PS01, PS02, PS03, PS04 and PS05 (Singh et al., 2017) PS01 and PS-03 are Bacillus species (Gen Bank accession number KU925853, KU925855 for PS-01 and PS-03 respectively) while the PS-
02, PS-04 and PS-05 isolates were identified as Microbacterium sp., Pseudomonas sp., and Arthobacter sp. (GenBank accession number KU925854, KU925856 and KU925857 for PS-02, PS-04 and PS-05 respectively).

\section{Mycorrhiza culture}

Mycorrhizal culture was obtained from Rhizospere Biology Lab, Department of Life Sciences, Shri Guru Ram Rai Institute of technology and Science, Dehradun, Uttarakhand, India.

\section{Green house experiments}

\section{Seeds and soil}

Seeds of pearl millet pant 5 (Pennisetum glaucum) were collected from Breeder Seed Production Centre, GBPUAT Pantnagar. Seeds were surface sterilized with $1 \%$ sodium hypochlorite for $30 \mathrm{sec}$ and rinsed with double distilled water thrice before use in greenhouse experiment. (Singh et. al, 2014)Soil used in the experiment was collected from the agricultural land near Guru Ram Rai Institute of Technology and Sciences, Dehradun. The soil was dried and sieved to $2 \mathrm{~mm}$ before mixing it with cow dung manure (3:1) and autoclaved twice for $1 \mathrm{~h}$ prior to pot experiment. The chemical characteristics of soil mixture were also analyzed; used soil mixture contained $215.2 \mathrm{~kg} \mathrm{ha}^{-1}$ potassium, $180.7 \mathrm{kgha}^{-1}$ nitrogen, $25.22 \mathrm{kgha}^{-1}$ phosphorus, $1.2 \%$ organic acid content, 0.163 milisimon electrical conductivity, and $6.75 \mathrm{pH}$ and the texture of soil was silt clay loam.

\section{Seed bacterization and pot experiment}

Bacterial culture were inoculated in $25 \mathrm{~mL} \mathrm{LB}$ in $100 \mathrm{~mL}$ conical flask and incubated at $37^{\circ} \mathrm{C}$, 120rpm. Colony forming units (cfu) were counted and bacterial inoculums containing 
approximately $1 \times 10^{8} \mathrm{cfu} / \mathrm{mL}$ were used for seed bacterization. CMC (Carboxy Methyl Cellulose) (100mg) was added to flask containing bacterial culture inoculum as adhesive material. 50 seeds were soaked in bacterial suspension for $12 \mathrm{~h}$ on a rotary shaker at $120 \mathrm{rpm}$. The bacterial suspension was drained and the seeds were dried overnight aseptically in laminar air flow. Seeds soaked in distilled water and with CMC served as control. The plants were grown in greenhouse under day/night cycle of $15 / 9 \mathrm{~h}$, $25 / 20^{\circ} \mathrm{C}$, and $65 \%$ relative humidity. Pot soil (soil: decomposedcowdungmanureat $3: 1 \mathrm{v} / \mathrm{v}$ ) was filled in to pots $(20 \mathrm{~cm}$ diameter $) .3$ bacterized seeds of pearl millet were sown in each pot in three replicates.

\section{Mycorrhiza infection}

Mycorrhiza infection was given by standard protocol developed by Phillips and Hayman 1970.

\section{Nutrient content estimation}

Nitrogen content was estimated according to Kjehaldal Method using KJEL PLUS System (Pelican, India).

\section{Phosphorus content estimation}

Phosphorus was estimated by method described in Jackson (1973).

\section{Potassium content estimation}

Potassium was determined by using flame photometer (Flame Photometer 128 Systronics)

\section{Biochemical and enzymatic estimation}

\section{Flavonoids estimation}

Total flavonoids was estimated by the method described by Ordonez et al., (2006).

\section{Phenol content estimation}

Total phenol content was estimated by Zieslin and Ben-Zaken (1993).

\section{SOD content estimation}

SOD was estimated by the method given by Beauchamp and Fridovich (1971).

\section{Results and Discussion}

Phosphorus solubilization is one of the most important mechanisms through which plant growth promoting isolates promote plant growth, but this is not the only way of plant growth promotion. There are several other mechanisms like direct stimulation, production of gibberellins, cytokinin, ACC deaminase, and volatile compounds that are also reported previously (Podile and Kishor et al., 2006) which were not characterized in the present study. Pearl millet seeds bacterized with rhizospheric isolates and infected with mycorrhiza (Figure 1) showed significant increased shoot length, root length, fresh weight, dry weight, root volume and root weight over control. Also, all bacterial isolates inoculated plants culture showed an increased inorganic $\mathrm{P}$ content in seedlings. PS-05 inoculated plant showed highest increase in root length $(12.40 \mathrm{~cm})$ dry weight (0.88 gm), fresh weight (9.53 gms), root volume $(3.80 \mathrm{ml})$, root weight $(2.42 \mathrm{~cm})$ and PS-04 inoculated plants showed highest increase in shoot length $(41.10 \mathrm{~cm})$ (Table1). It was assumed that one or many of these traits may be involved in the plant growth promoting activity by isolates PS-01, PS-02, PS-03, and mycorrhiza. Our result showed the successful screening of the bacterial isolates for in vitro solubilization of inorganic phosphate and their effects on fresh weight, dry weight, root length, and shoot length of Pearl millet seedlings. Seedlings containing PS-05 showed highest P content of 111.28 
$1.29 \mathrm{mg} / \mathrm{g}$. Seedlings raised from seeds bacterized with PGPB isolates showed higher accumulation of phosphorus content than inoculated control. Among them isolate PS05treatment showed significant increase in accumulation of phosphorous in comparison with control.

Isolate PB-05 was also found significantly increasing dry weight of seedlings in comparison to control (Table 1). Several rhizobacteria can solubilize inorganic phosphate from soil and such bacteria improve solubilization of unavailable soil phosphate resulting in a high efficiency of phosphorus use. When rhizosphere soil samples of 30d old seedlings, with all PSRB isolates, were analyzed, not much variations in $\mathrm{pH}$ was observed. There were no significant changes in $\mathrm{pH}$ of soil samples collected from different seedlings (Figs. 2 and 3 ; Tables 1 and 2).

In conclusion, all studied bacterial isolates from Himalayan soils showed ability to harbor diverse plant growth promoting activities, including production of ammonia, siderophores and indoleacetic acid, releasing of $\mathrm{P}$ from insoluble inorganic phosphates. Also, the inoculation of Pearl millet seeds with PS-01, PS-02, PS-03, PS-04, PB-05 and mycorrhiza showed improved $\mathrm{P}$ content, fresh wet, dry wet, nitrogen content, potassium content and growth of Pearl millet.

Fig.1 Mycorrhiza infection in pearl millet root
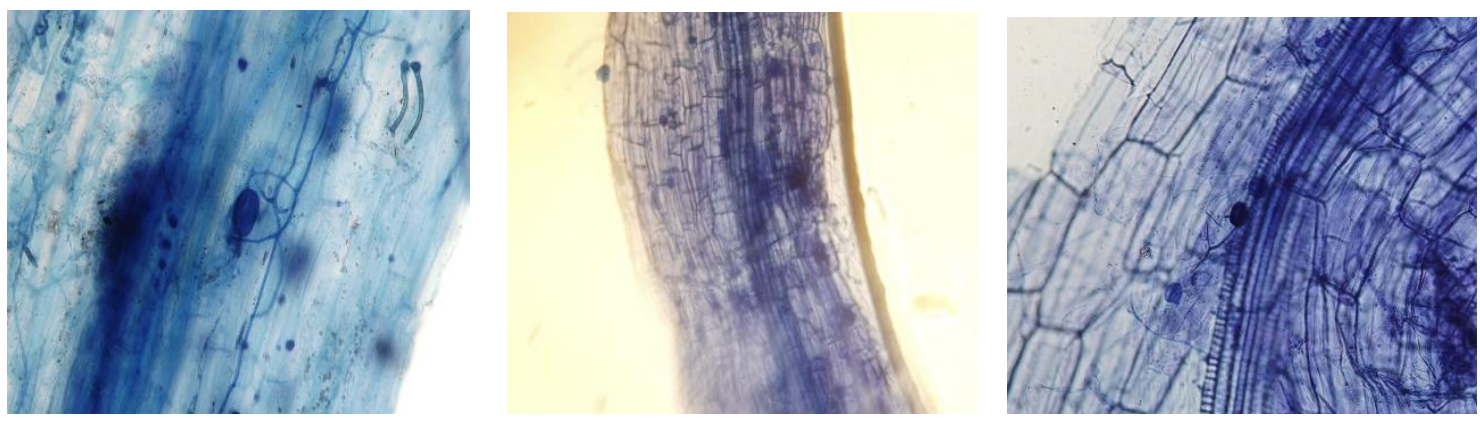

Fig.2 Rhizobacteria and mycorrhizal treatment effect on root of pearl millet plant

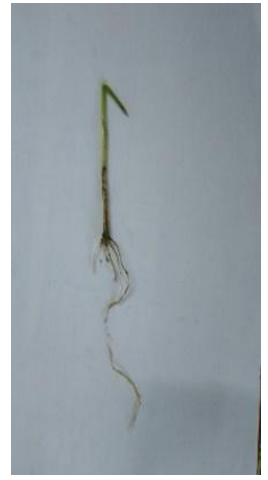

Control

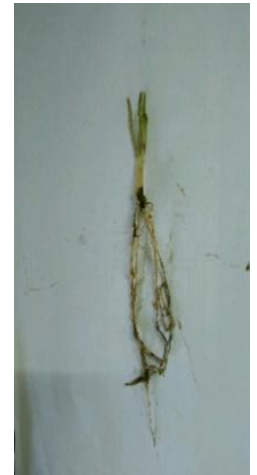

PS -01

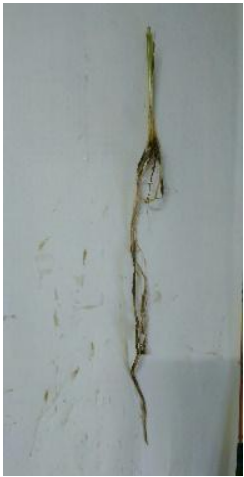

PS-02

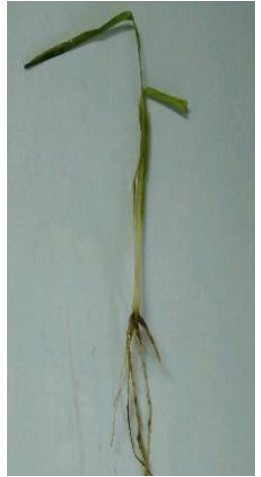

PS -03 


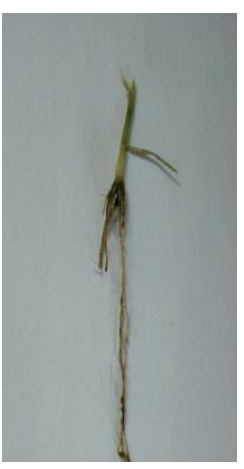

PS -04

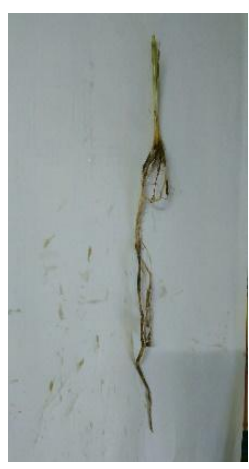

PS -05

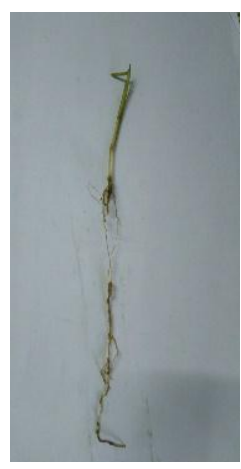

Mycorrhiza

Table.1 Effect on physiological parameters of pearl millet with rhizobacteria and mycorrhizal treatment

\begin{tabular}{|l|l|l|l|l|l|l|}
\hline Culture & $\begin{array}{l}\text { Shoot } \\
\text { Length }(\mathbf{c m})\end{array}$ & $\begin{array}{l}\text { Root Length } \\
(\mathbf{c m})\end{array}$ & $\begin{array}{l}\text { Fresh } \\
\text { Weight }(\mathbf{c m})\end{array}$ & Dry Weight (g) & $\begin{array}{l}\text { Root } \\
\text { Volume (ml) }\end{array}$ & $\begin{array}{l}\text { Root Weight } \\
(\mathbf{g})\end{array}$ \\
\hline Control & $30.27^{\mathrm{a}} \pm 0.46$ & $10.15^{\mathrm{a}} \pm 0.04$ & $7.83^{\mathrm{a}} \pm 0.15$ & $0.51^{\mathrm{a}^{\mathrm{a}}} \pm 0.017$ & $2.50^{\mathrm{a}} \pm 0.04$ & $1.88^{\mathrm{a}} \pm 0.02$ \\
\hline PS 01 & $36.60^{\mathrm{c}} \pm 0.46$ & $11.37^{\mathrm{bc}} \pm 0.26$ & $8.43^{\mathrm{b}} \pm 0.09$ & $0.80^{\mathrm{bc}} \pm 0.023$ & $3.62^{\mathrm{c}} \pm 0.03$ & $2.03^{\mathrm{b}} \pm 0.04$ \\
\hline PS 02 & $41.03^{\mathrm{a}} \pm 0.26$ & $11.93^{\mathrm{c}} \pm 0.15$ & $8.33^{\mathrm{b}} \pm 0.15$ & $0.83^{\mathrm{c}^{\mathrm{c}} \pm 0.032}$ & $3.31^{\mathrm{b}} \pm 0.04$ & $2.26^{\mathrm{c}} \pm 0.05$ \\
\hline PS 03 & $34.20^{\mathrm{b}} \pm 0.44$ & $11.00^{\mathrm{b}} \pm 0.32$ & $7.97^{\mathrm{a}} \pm 0.09$ & $0.75^{\mathrm{b}} \pm 0.023$ & $3.51^{\mathrm{c}} \pm 0.04$ & $2.13^{\mathrm{bc}} \pm 0.06$ \\
\hline PS 04 & $40.10^{\mathrm{e}} \pm 0.21$ & $11.93^{\mathrm{c}} \pm 0.30$ & $7.80^{\mathrm{a}} \pm 0.06$ & $0.73^{\mathrm{b}} \pm 0.021$ & $3.27^{\mathrm{b}} \pm 0.04$ & $2.25^{\mathrm{c}} \pm 0.05$ \\
\hline Ps 05 & $41.07^{\mathrm{a}} \pm 0.57$ & $12.40^{\mathrm{c}} \pm 0.25$ & $9.53^{\mathrm{c}} \pm 0.09$ & $0.88^{\mathrm{c}} \pm 0.018$ & $3.80^{\mathrm{d}} \pm 0.03$ & $2.42^{\mathrm{d}} \pm 0.03$ \\
\hline Mycorrhiza & $38.03^{\mathrm{d}} \pm 0.20$ & $12.17^{\mathrm{c}} \pm 0.34$ & $7.90^{\mathrm{a}} \pm 0.06$ & $0.76^{\mathrm{bc}} \pm 0.015$ & $3.59^{\mathrm{c}} \pm 0.03$ & $2.11^{\mathrm{b}} \pm 0.03$ \\
\hline
\end{tabular}

Table.2 Effect on biochemical parameters of pearl millet with rhizobacteria and mycorrhizal treatment

\begin{tabular}{|c|c|c|c|c|c|c|}
\hline Culture & $\begin{array}{l}\text { Nitrogen } \\
(\%)\end{array}$ & Phosphorus(mg/g) & $\begin{array}{l}\text { Potassium } \\
(\mathrm{mg} / \mathrm{g})\end{array}$ & $\begin{array}{l}\text { Phenols } \\
\text { (mg/g) }\end{array}$ & $\begin{array}{l}\text { SOD } \\
\text { (Unit/g) }\end{array}$ & $\begin{array}{l}\text { Flavonoids } \\
(\mu \mathrm{g} / \mathrm{g})\end{array}$ \\
\hline Control & $\begin{array}{l}1.70^{\mathrm{ab}} \pm \\
0.02\end{array}$ & $49.87^{\mathrm{a}} \pm 1.00$ & 0.079 & $\begin{array}{l}11.24^{\mathrm{a}} \pm \\
0.49\end{array}$ & $\begin{array}{l}9.44^{\mathrm{a}} \pm \\
0.08\end{array}$ & $34.31^{\mathrm{a}} \pm 0.83$ \\
\hline PS 01 & $\begin{array}{l}1.83^{\mathrm{b}} \pm \\
0.03\end{array}$ & $96.34^{\mathrm{c}} \pm 0.79$ & 0.105 & $\begin{array}{l}13.04^{\mathrm{b}} \pm \\
0.30\end{array}$ & $\begin{array}{l}11.35^{\mathrm{c}} \pm \\
0.05\end{array}$ & $36.22^{\mathrm{b}} \pm 0.38$ \\
\hline PS 02 & $\begin{array}{l}2.36^{\mathrm{c}} \pm \\
0.05\end{array}$ & $96.91^{c} \pm 0.83$ & 0.094 & $\begin{array}{l}17.29^{\mathrm{c}} \pm \\
0.44\end{array}$ & $\begin{array}{l}10.27^{\mathrm{b}} \pm \\
0.04\end{array}$ & $35.81 \mathrm{a}^{\mathrm{b}} \pm 0.54$ \\
\hline PS 03 & $\begin{array}{l}2.57^{\mathrm{d}} \pm \\
0.06\end{array}$ & $92.15^{b} \pm 0.85$ & 0.099 & $\begin{array}{l}17.08^{\mathrm{c}} \pm \\
0.65\end{array}$ & $\begin{array}{l}11.60^{\mathrm{c}} \pm \\
0.12\end{array}$ & $38.20^{c} \pm 0.51$ \\
\hline PS 04 & $\begin{array}{l}2.87^{\mathrm{e}} \pm \\
0.03\end{array}$ & $95.63^{\mathrm{c}} \pm 0.48$ & 0.112 & $\begin{array}{l}17.33^{\mathrm{c}} \pm \\
0.67\end{array}$ & $\begin{array}{l}10.69^{b} \pm \\
0.23\end{array}$ & $38.08^{c} \pm 0.63$ \\
\hline Ps 05 & $\begin{array}{l}2.58^{\mathrm{d} \pm} \pm \\
0.03\end{array}$ & $111.28^{\mathrm{d}} \pm 1.29$ & 0.132 & $\begin{array}{l}20.74^{\mathrm{d}} \pm \\
0.56\end{array}$ & $\begin{array}{l}10.16^{\mathrm{b}} \pm \\
0.34\end{array}$ & $46.57^{\mathrm{e}} \pm 0.44$ \\
\hline Mycorrhiza & $\begin{array}{l}2.49^{\mathrm{d}} \pm \\
0.04\end{array}$ & $93.74^{\mathrm{bc}} \pm 0.80$ & 0.13 & $\begin{array}{l}20.88^{\mathrm{d}} \pm \\
0.35\end{array}$ & $\begin{array}{l}10.27^{\mathrm{b}} \pm \\
0.27\end{array}$ & $42.02^{\mathrm{d}} \pm 0.68$ \\
\hline
\end{tabular}


Fig.1 Rhizobacteria and Mycorrhiza treated seedlings of Pennisetum glaucum (L) after 30 days of germination. Last one in each image served as control for experiment

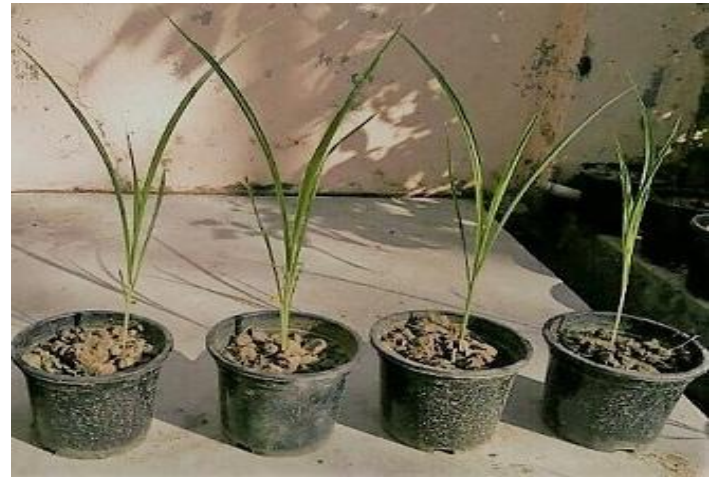

PS-01 treated Pearl millet plant

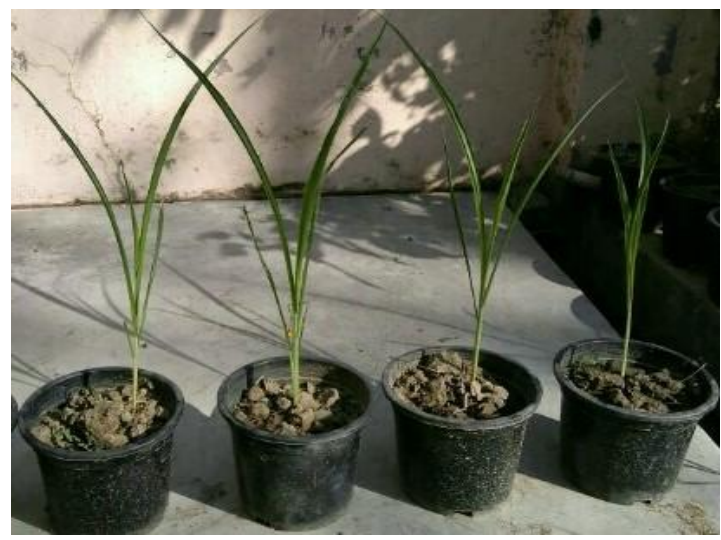

PS-03 treated Pearl millet plant

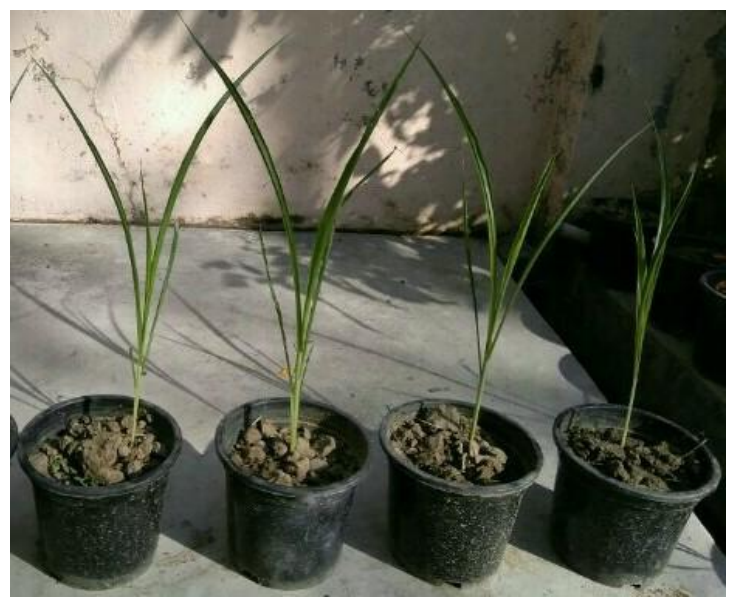

PS-05 treated Pearl millet plant

PGPRs and mycorrhiza treated plants showed higher contents of secondary metabolites like phenols and flavonoids, which is also confirmed by other researchers. Such an

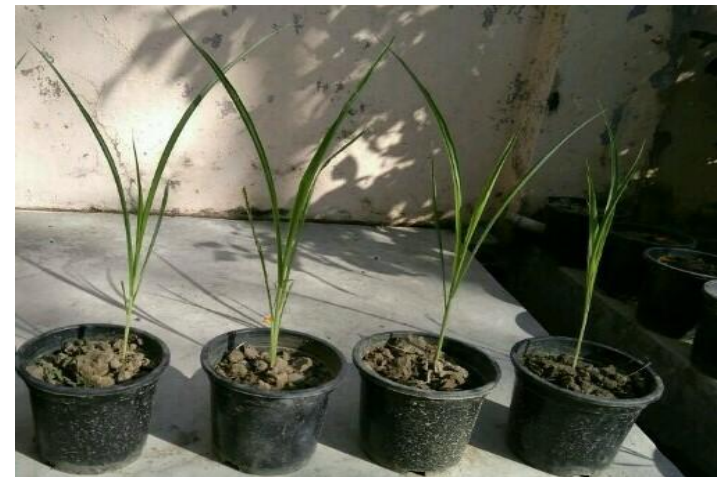

PS-02 treated Pearl millet plant

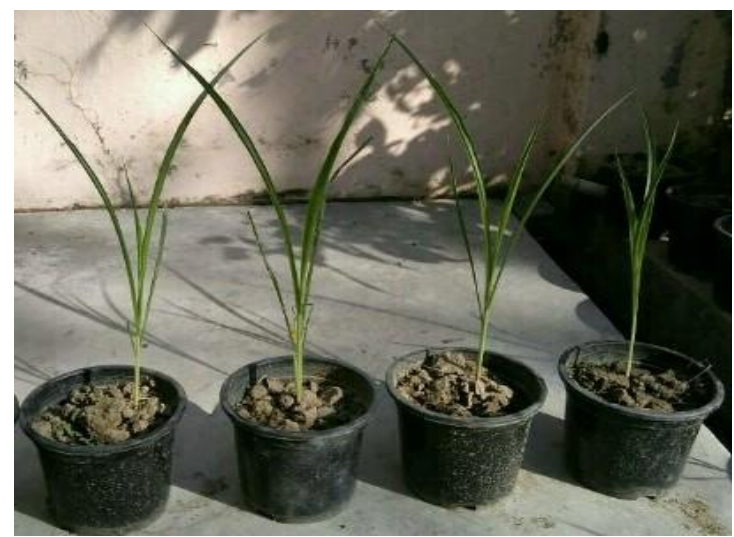

PS-04 treated Pearl millet plant

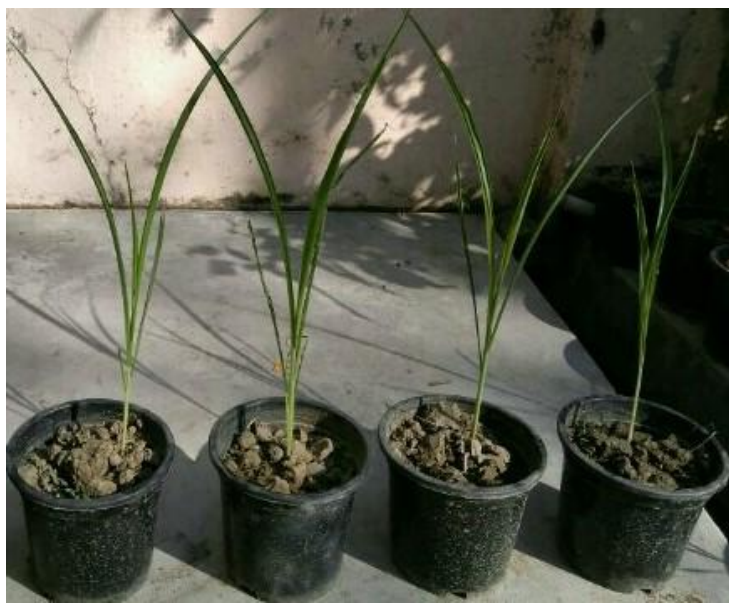

Mycorrhiza treated Pearl millet plant

increased content of secondary metabolites due to Mycorrhizal inoculation with PGPR's was reported by earlier workers (Selvaraj et al., 2008). Since oxygen appeared in the 
biosphere some 3-5 billion years ago, all organisms have to deal with the hazards of potentially damaging reactive oxygen species (ROS), such as superoxide, hydrogen peroxide, and hydroxyl radical. Like all organisms, pathogenic microbes produce reactive oxygen species as byproducts of aerobic metabolism, but the burden of ROS is magnified when these microbes confront the oxidative burst of the host. As part of the innate immune response, macrophages and neutrophils attack invading microbes with toxic superoxide (Fenlon et al., 2014).To counteract this attack, some microbial pathogens express superoxide dismutase enzymes (Chynna et al., 2016). All PGPRs and mycorrhiza treated pearl millet plants showed more SOD content in comparison to control (Table 2). The present study clearly revealed that all isolates tested in this study had the ability to solubilize inorganic phosphate, ammonia and IAA and increased availability of $\mathrm{P}$ and ammonia leading to increased plant growth. These isolates may be further characterized using molecular approaches and changes in expression of related genes for in-depth understanding of detailed mechanism of plant growth promotion. The isolates may also be used in development to suitable liquid bio fertilizer, employing a consortium of such kind of plant beneficial microbes. Such kind of microbes also may be beneficial for organic farming.

\section{References}

Beauchamp, C.O., Fridovich, I. (1971): Superoxide dismutase: improved assay and an assay applicable to acrylamide gels. Anal. Biochem. 44, 276-287 (1971)

Bhatnagar, S.K., Khairwal, I.S., Pareek, S. (2002) Pearl millet nucleus and breeder seed production. Technical bulletin. Project coordinator (Pearl millet). All India coordinated pearl millet improvement project (AICPMIP), Jodhpur, India

Chynna, N., Broxton, Valeria, C. and Culotta (2016) SOD Enzymes and Microbial Pathogens: Surviving PLOS Pathogens doi:10.1371/journal.ppat.1005295

Correa, J.D., Barrios, M.L., Galdona, R.P. (2004) Screening for plant growthpromoting rhizobacteria in Chamaecytisusproliferus (tagasaste), a forage tree-shrub legume endemic to the Canary Islands. Plant Soil 266:75-84

Fenlon, L.A., Slauch,J.M. (2014), Phagocyte roulette in Salmonella killing.CellHostMicrobe,15(1):7-8. doi:10.1016/j.chom.2014.01.001S19313128

Haggag, W.M. (2002) Sustainable agriculture management of plant diseases. J BiolSci 2(4):280-284.

Han, J., Sun, L., Dong, X., Cai, Z., Yang, H., Wang, Y., Song, W. (2005) Characterization of a novel plant growth-promoting bacteria strain Delftiatsuruhatensis HR4 both as a diazotroph and a potential biocontrol agent against various pathogens. SystApplMicrobiol 28:66-76

Jackson, M.L. (1973): Soil chemical analysis, Prentice Hall of India, New Delhi. India (1973).

Khalid, A., Arshad, M., Zahir, Z.A. (2004) Screening plant growth promoting rhizobacteria for improving growth and yield of wheat. J ApplMicrobiol 96:473-480

Kloepper, J.W. (1993) Plant growthpromoting rhizobacteria as biological control agents. In: Metting FB Jr (ed) Soil microbial ecology. Marcel Dekker, New York, pp. 255-274

Normander, B., Prosser, J.I. (2000) Bacterial origin and community composition in the barley phytosphere as a function of habitat and presowing conditions. Appl Environ Microbiol 66:4372- 4377 
Ordonez, A.A.L., Gomez, J. D., Vattuone M. A. and IIsla M. I. (2006). Antioxidant activities of Sechiumedule (Jacq). Food Chem., 97: 452-458.

Pal, K.K., Tilak, K.V.B.R., Saxena, A.K., Dey, R., Singh, C.S. (2001) Suppression of maize root diseases caused by Macrophomina phaseolina, Fusarium moniliforme and Fusarium graminearum by plant growth promoting rhizobacteria. Microbiol Res 156:209-223

Phillips, J. M., and D. S. Hayman D. S. (1970). Improved procedures for clearing roots and staining parasitic and vesicular-arbuscular Mycorrhizal fungi for rapid assessment of infection. Trans. Br. Mycol. Soc. 55:158-161.

Podile, R. and G. K. Kishor, G.K.(2006)"Plant growth promoting rhizobacteria,"in Plant Associated Bacteria, S.S. Gnanamanickam, Ed.,pp.195-

230,Springer,Dordrecht, TheNetherlands ,2006.

Raj, S.N., Deepak, S.A., Basavaraju, P., Shetty, H.S., Reddy, M.S., Kloepper, J.W. (2003) Comparative performance of formulations of plant growth promoting rhizobacteria in growth promotion and suppression of downy mildew in pearl millet. Crop Prot 22:579-588

Renwick, A.R., Campbell, A., Coe, S. (1991) Assessment of in vivo screening systems for potential biocontrol agents of Gaeumannomyces graminis. Plant Physiol 40:524-532

Rodriguez, H., Fraga, R. (1999) Phosphate solubilizing bacteria and their role in plant growth promotion. BiotechnolAdv 17: 319-339

Selvaraj, T., S. Rajeshkumar, S., M.C. Nisha, M.C., L. Wondimu L. and MitikuTesso, M. (2008). Effect of Glomusmosseae and plant growth promoting rhizo microorganisms (PGPR's) on growth. Nutrients and content of secondary metabolites in Begonia malabarica Lam. Mj. Int. J. Sci. Tech., 2, 516-525 (2008).

Singh, P., Kumar, V. and Agarwal, S. (2014) Evaluation of phytase producing bacteria for their plant growth promoting activities. International Journal of Microbiology

Singh, P.,Suyal, D.C., Naveen Kumar,N., Manish Dev Sharma, M.D., Indra Rautela, I., Aditya Patel, A., Narottam Sharma, N. and Veena Pandey, V. (2017) Isolation and molecular characterization of plant growth promoting rhizobacteria from the high altitude Himalaya region of Uttarakhand. Journal of Plant Development Sciences 9 (3).

Zieslin, N. and Ben- Zaken, R. (1993). Peroxidase activity and presence of phenolic substances in peduncles of rose flowers. Plant Physiol.8iochem. 31: 333-339

\section{How to cite this article:}

Prashant Singh, Hem C. Joshi, Naveen Kumar, Manish Dev Sharma, Aditya Patel, Narottam Sharma and Veena Pandey. 2017. Evaluation of Plant Growth Promoting Rhizobacteria and Mycorrhizal Fungi for Growth and Nutrient Uptake in Pearl Millet (Pennisetum glaucum). Int.J.Curr.Microbiol.App.Sci. 6(6): 2648-2655. doi: https://doi.org/10.20546/ijcmas.2017.606.315 